Final version to appear in Nous.

\title{
Schopenhauer on the Content of Compassion
}

\author{
Colin Marshall
}

\begin{abstract}
On the traditional reading, Schopenhauer claims that compassion is the recognition of deep metaphysical unity. In this paper, I defend and develop the traditional reading. I begin by addressing three recent criticisms of the reading from Sandra Shapshay: that it fails to accommodate Schopenhauer's restriction to sentient beings, that it cannot explain his moral ranking of egoism over malice, and that Schopenhauer requires some level of distinction to remain in compassion. Against Shapshay, I argue that Schopenhauer does not restrict compassion to sentient beings and that a more metaphysically refined version of the traditional reading can accommodate both Schopenhauer's moral ranking of characters and allow for some level of distinction in compassion. I then turn to four further questions for the traditional reading: what the relation is between the feeling of compassionate pain and the recognition of metaphysical unity, how cognitions mediate compassion, whether compassion is limited to the present, and how the feeling of compassion relates to Schopenhauer's fundamental moral principle. I conclude by explaining how, in a reductive vein, the traditional reading can also allow for compassion to have normative content.
\end{abstract}

What, if anything, does compassion tell us about the world? To answer this question, we might compare compassion with ordinary perceptual experience. Ordinary perception informs us about objects outside our minds. A visual perception, for example, might clue me into the fact that a grey squirrel is climbing onto my birdfeeder. In contemporary philosophical terms, the "that" clause in the previous sentence reports the content of the visual state. This content might be true or false, but its presence in perception helps make some beliefs justified or appropriate for the perceiving subject to hold.

Does compassion, like perception, have content and if so, what is it? In the European intellectual tradition, the philosopher with the most radical views on the topic is probably Arthur Schopenhauer. Sorting through Schopenhauer's views provides an opportunity for getting clearer on the representational dimensions of compassion.

Readings of Schopenhauer's views on the content of compassion fall into two general camps. According to one interpretative approach, its content is a radical metaphysical claim concerning the non-distinctness of individuals, a claim Schopenhauer takes to be true. This 'monist' interpretation is inspired by passages like the following:

plurality and difference belongs solely to mere appearance, and... one and the same essence... presents itself in everything that lives... [T] he basis of the phenomenon of compassion... the metaphysical basis of ethics... consist [s] in one individual's immediately recognizing himself, his own true essence, in the other. (OBM 4:270, 253)

A good conscience comes from the fact that unselfish deeds, arising out of the immediate recognition of our own essence in other appearances, confirm the recognition that our true self does not exist only in the single appearance of our own person, but in every living thing (WWRI 2:441, 400) 
All genuine virtue proceeds from the immediate and intuitive knowledge of the metaphysical identity of all beings [metaphysischen Identität aller Wesen] (WWRII $2: 690,601) 1$

Schopenhauer seems to hold that compassion informs us about the truth of radical metaphysical monism, on which we are not really distinct from, say, the hungry squirrel for whom we might (or might not) feel compassion. That has the surprising consequence that compassion conflicts with ordinary perceptions, which seem to inform us that the squirrel is genuinely distinct from us.

Another interpretive approach, which Christopher Janaway has dubbed the 'axiological' interpretation, instead takes the content for Schopenhauer to be primarily evaluative.2 Since the axiological interpretation can remain neutral on metaphysical monism, it can avoid positing any conflict between compassion and ordinary perception. In recent work, Sandra Shapshay has defended a novel version of the axiological interpretation (though it has some precedent in Iris Murdoch3). On her reading, which she dubs the 'inherent value interpretation,' Schopenhauer holds that compassion informs us that other sentient beings have inherent moral value. Shapshay takes Schopenhauer to be appealing to a form of non-reductive moral realism here, on which the fact that others have inherent value has no deeper explanation. So when Schopenhauer claims that compassion reveals to us that our own "inner essence exists in every living thing" (OBM 4:271, 254), Shapshay suggests we take "essence" to have a purely normative significance, meaning "inherent value."4

My aim in this paper is to develop and defend a form of the monist interpretation. While the Monist Interpretation has been regarded as the default reading in most of the secondary literature, Shapshay raises three important criticisms of it that call for answers. In addition, close attention to the text presents a number of interpretive questions that require refining the interpretation beyond what previous commentators (myself includeds) have done. The refined monist interpretation has Schopenhauer offering an intricate, provocative view that offers a unique perspective on the content of compassion.

Three notes before proceeding. First, I should acknowledge a problem in applying the contemporary notion of content to Schopenhauer. The contemporary notion is most comfortably understood in a broadly linguistic framework, where a mental state has proposition $\mathrm{P}$ as its content just in case it (defeasibly) positions its subject to sincerely state a sentence with the content P. 6 This is convenient for writing about content, since it allows sentences to reflect the content of mental states. For Schopenhauer, however, language is a tool for expressing only conceptual representation, whereas compassion is based in non-conceptual, 'intuitive' representation that "cannot be communicated through words" (WWRI 2:434, 395). Yet Schopenhauer himself uses words to describe the insight involved in compassion, so he must hold

1 For references to Schopenhauer's texts, I provide an abbreviated title, the volume and page number in the Hübscher edition of Schopenhauer's works, followed by the page number in the relevant English translation listed in Works Cited below. I use the following abbreviations for Schopenhauer's works: WWRI = World as Will and Representation, Volume I; WWRII, World as Will and Representation, Volume II; FW = "Prize Essay on the Freedom of the Will"; OBM = "Prize Essay on the Basis of Morals"; $\mathrm{P} \& \mathrm{PII}=$ Parerga and Paralipomena , Volume 2.

2 Janaway 2007, 61. See also Reginster 2015.

3 See Murdoch 1993, 65, 73.

4 Shapshay 2019a, 185.

5 Marshall 2017a, Marshall 2017b.

6 The exact link between mental content and linguistic behavior is more complex than this, of course (see, e.g., Kripke 1979). 
that sentences can be used to at least gesture at what this insight involves - perhaps in a metonymic way.7

Second, the axiological claim that we share inherent value with other beings does not imply any radical monist metaphysics, nor does monism imply any shared value. Hence, the inherent value interpretation and the monist interpretation are logically independent. They are compatible, but Schopenhauer does not suggest that compassion has a two-tiered content (though he does suggest there are different levels of compassionate insight). Hence, if we have strong grounds for accepting both, we might suspect that Schopenhauer accepts some reductive metaethical theory, on which the truth of monism transparently grounds the truth of our shared inherent value. Such a reductive theory would imply that a grasp of the monist truth amounts to a grasp of the evaluative claim. This is not a possibility Janaway or Shapshay explores, 8 and I will return to it later. My main focus, though, is finding the exegetically best form of the monist interpretation.

Third, many commentators, while acknowledging the monist elements of Schopenhauer's ethical views, have offered revisions of his ethical views that bypass monism.9 I think this revisionist project is a worthwhile, and have elsewhere defended a non-monist neo-

Schopenhauerian metaethical view.10 However, I think that there may be surprising pay-offs to understanding the details of how monism plays into Schopenhauer's ethics. Hence, the present paper focuses on figuring out Schopenhauer's actual views, not how they might be productively revised.

\section{Shapshay's criticisms of the monist interpretation}

Shapshay grants that taking compassion to involve "an intuitive grasp of the nonindividuated nature of the metaphysical will" is "certainly a justified reading" of the key passages from OBM.11 She holds, however, that the monist interpretation faces certain textual problems that the inherent value interpretation does not, and implies that, in virtue of avoiding radical metaphysical commitments, the latter reading is more philosophically attractive.12 For present purposes, I bracket most issues of philosophical attractiveness and focus on Shapshay's textual arguments.

As I read her, Shapshay provides three important criticisms of the monist interpretation, which she understands as construing the content of compassion as follows: "I (the compassionate person) recognize intuitively that the suffering other and I both share the same essence in itself, namely, the unindividuated metaphysical Will." 13 I will refer to this as the "simple monist interpretation.' While two of Shapshay's criticisms can, I think, be answered by merely clarifying that reading, the other criticism requires going beyond the simple monist interpretation.

\footnotetext{
7 Shapshay 2008.

8 Shapsahy briefly acknowledges the in-principle compatibility of the readings in Shapshay 2019b, 16. Janaway seems to acknowledge the compatibility as well though, like Shapshay, his emphasis is on how much of Schopenhauer's view can be separated off of his monism (Janaway 2007, 61-2).

9 This includes Shapshay 2019, Reginster 2015, Cartwright 2008, Janaway 2007, Young 2005, and Welchman unpublished.

10 Marshall 2018, which shares some affinities with the proposal in Welchman unpublished.

11 Shapshay 2019b, 3.

12 Shapshay 2019a, 187.

13 Shapshay 2019b, 12. Shapshay divides up her criticisms somewhat differently than I do, but not in ways that will affect my argument.
} 


\subsection{Restriction to living beings}

Schopenhauer treats OBM as his most complete and detailed presentation of his ethical system (see WWRI 2:446, 404). In OBM, Schopenhauer seems to limit the scope of compassion to sentient beings. For example: "My true, inner essence exists in every living thing as immediately as it reveals itself in my self-consciousness to myself alone" (OBM 4:271, 254). Moreover, all Schopenhauer's examples of compassion concern humans and non-human animals. Hence, David Cartwright claims that it is "uncontroversial" that, for Schopenhauer, "compassion is a relationship between sentient beings... One could not have compassion for a mountain" (Cartwright 2012, 259). Yet, Shapshay points out, Schopenhauer's monist metaphysical view is that all things whatsoever - sentient or not - have the will as their essence. Hence, if the simple monist interpretation were correct, we would expect Schopenhauer to include all objects within the scope of compassion without restriction. Since he apparently does not, Shapshay suggests, we have reason to reject the simple monist interpretation. 14

This objection can be answered by clarifying the simple monist interpretation. Shapshay is right, I believe, that the simple monist interpretation suggests that, in principle, compassion is possible with non-sentient things, and this point has often been missed by earlier commentators.15 However, Schopenhauer might have simply been leaving this implication of his views out of OBM for presentational purposes. More importantly, there is some textual reason to think that Schopenhauer accepted compassion for non-sentient beings. In WWRI, he writes that,

the noble-minded sort of person... recognizes, immediately and without inference, that the in-itself of his own appearance is the in-itself of other people's too, that it is the will to life, and that it constitutes the essence of every single thing and is alive in all things; indeed, he recognizes that this extends even to animals and the whole of nature (WWRI $2: 440,399)$

By adding the phrase "the whole of nature" after "animals," Schopenhauer indicates that compassion can be felt for non-sentient beings. To appreciate why this is not an obviously absurd view, note that Schopenhauer's claim that the will is "alive in all things" suggests a form of panvitalism. He is more explicit about this pan-vitalism elsewhere, stating that "it is a mere pleonasm and amounts to the same thing if, instead of simply saying 'the will', we say 'the will to life", (WWRI 2:324, 301).16 Hence, saying that compassion extends 'only' to living things is not to restrict the scope of compassion, for Schopenhauer, since everything has the will to life as its essence. Schopenhauer's discussion of the conflict inherent to all aspects of nature brings out his pan-vitalism vividly:

Everywhere in nature we see conflict, we see struggle... Each level of the will's objectivation is in conflict with the others over matter, space and time. The underlying, persisting matter must constantly change form as mechanical, physical, chemical and organic appearances... all crowd around, greedy to emerge and tear the matter away from the others (WWRI 2:174-5, 171)

Moreover, Schopenhauer's general theory of suffering arguably implies that everything with will (i.e. everything) can suffer. He states that "all suffering is nothing other than unfulfilled and

14 Shapshay 2019b, 8; Shapshay 2019a, 187-190.

15 One notable exception is Varner 1985.

16 As Shapshay herself argues, much of Schopenhauer's language is metonymic (Shapshay 2019, 49-51), so his use of 'life,' 'living,' etc. may often be as well. 
thwarted willing" (WWRI 2: 429, 390). While he does not offer details on the suffering of nonsentient beings, he does note that "even the vegetative part of our life is always accompanied by a quiet suffering" (WWRI 2:174, 171). Hence, even restricting compassion to things with the capacity for suffering, for Schopenhauer, is not a restriction to sentient beings.

Why, then, does Schopenhauer not offer any concrete examples of compassion for plants or inorganic objects? Shapshay herself provides the material for an answer here. She notes that "Schopenhauer's system is in general characterized by degrees", 17 and that this suggests he believes different beings have different degrees of moral importance. For example, just after the claim about compassion for "the whole of nature," Schopenhauer states:

People's rights to the lives and powers of animals are based on the fact that, because suffering increases along with the increase in the clarity of consciousness, the pain that animals suffer in death or work is not as great as that which humans suffer by doing without meat or animal power. (WWRI 2:440, 399)

As we saw above, Schopenhauer seems committed to allowing even inorganic objects to suffer, since everything wills, and suffering just is unfulfilled and thwarted willing. Yet the suffering becomes less at lower levels of consciousness (even, at a vegetative level 'quiet'), and lower, non-conscious levels of suffering call for less consideration.18 If the suffering of non-human animals is not sufficient to prohibit our eating them, then the suffering of plants and inorganic objects would be too negligible to be worth mentioning. 19

\subsection{Contrast with malice}

Schopenhauer claims that malice is morally worse than egoism, making the former the defining characteristic of evil (WWRI 2:428,389) and calling it "moral badness raised to a higher power" (OBM 4:200, 194). However, Shapshay points out, the egoist and the malicious person would seem to be equally lacking in insight into the truth of metaphysical monism. Hence, the monist interpretation does not seem equipped to explain Schopenhauer's normative ranking of non-compassionate dispositions.20

While defenders of the monist interpretation have had little to say about malice, there are at least two possible ways to clarify the interpretation to accommodate this point. The first is take Schopenhauer's ranking to be based on the fact that only malice is the "direct opposite of compassion" (OBM 4:225, 215) in terms of what it disposes one to do. For Schopenhauer allows that one can rightly defend oneself from attack (e.g., OBM 4:222, 212), which seems to at least be consistent with some level of egoism, and states that "true friendship is always a mixture of selfishness and compassion" (WWRI 2:444, 403). Yet, on his view, no malicious actions are compatible with moral rightness (OBM 4:200, 193-4). However, Schopenhauer implies that the

17 Shapshay 2019, 188.

18 As Eric Aston pointed out to me, when he defends the moral considerability of non-human animals, Schopenhauer appeals to our shared will, not our shared intellect (OBM 4:241, 228). Of course, though he claims that all things have will as their inner essence, Schopenhauer cautions us not to understand "will" in the ordinary sense, which implies abstract motives and reason (see WWRI 2:132, 136).

${ }_{19}$ Gary Varner also suggests that, since Schopenhauer did not believe in individual characters for most nonhumans (see below), he may have also held that the 'will' of things like hydrogen atoms is merely for there to be at least some instance of their species somewhere (Varner 1985, 221). If Varner is right, then the only way to injure or wrong such entities would be eliminate their entire kind - something rarely within our abilities.

20 Shapshay 2019b, 13-14 (cf. Shapshay 2019a, 183-4). 
malicious person is epistemically worse than the egoist (OBM 4:265, 249), so this first clarification does not seem sufficient. Fortunately, there is a second, more epistemological way for the monist interpretation to accommodate Schopenhauer's normative ranking. This would be to say that malicious motivation itself involves a commitment to others' reality, whereas egoistic motivation does not. As far as egoist motivation is concerned, others can be regarded "only as masks, lacking reality" (WWRI 2:429, 390), and so as not as equally real as herself. The malicious person, however, is motivated to promote others' internal suffering, and so must see them as equally real as herself. This motivational commitment therefore gives more weight to the apparent distinctness of fully-real individuals.21 Surprisingly, this means that the malicious person is, in one respect, epistemically better than the egoist: for only the former is (like the compassionate person) firmly committed to the inner reality of others. Importantly, however, Schopenhauer does not suggest that the malicious person is generally epistemically worse off than the egoist, only that, for her, the (illusory) spatiotemporal distinctions are more "great" ("grof" (OBM 4:264, 249)).22 By recognizing others' inner reality, the malicious person strengthens her mistaken commitment to their spatiotemporal distinctness from her, whereas the egoist is less committed to that distinction (as far as her motivations are concerned, the egoist could regard them all as figments of her own imagination). On other epistemic fronts, the malicious person might be epistemically better than the egoist or the compassionate person.

\subsection{Schopenhauer is not a simple monist}

On the simple monist interpretation, the compassionate person perceives that there is no distinction between herself and the object of her compassion, as some forms of metaphysical monism would imply.23 In some passages, Schopenhauer seems to state such a view. For instance:

if time and space is foreign to the thing in itself, i.e. to the true essence of the world, then necessarily plurality is foreign to it also: consequently in the countless appearances of this world of the senses it can really be only one... [A]ll plurality is only apparent (OBM $2: 267-8,251)$

[The assumption] that one and the same being could be in different places at the same time and yet wholly in each... is the most palpable impossibility, indeed an absurdity from an empirical point of view, still it remains absolutely true of the thing in itself, because this impossibility and absurdity rest merely on the forms of appearance... For the thing in itself, the will to life, is present in every being, even the slightest, wholly and undivided, as completely as in all beings that ever were, are and will be taken together. (P\&PII 6:236-36, 201)

However, Shapshay points out that Schopenhauer's description of compassion suggests (a) that some distinction is still involved in compassionate insight and (b) that Schopenhauer's larger metaphysics is not a simple monist one. I'll expand on each point in turn before offering refinements of the monist interpretation that address them.

21 In a similar vein, Reginster suggests that, on Schopenhauer's view, the egoist "fails to recognize or appreciate fully the reality of others with interests of their own" (Reginster 2015, 263).

22 Nor, for that matter, does he suggest that the compassionate person is generally epistemically better off than egoists.

23 Not all forms, however: an 'acosmist' monist would hold that there are no individuals besides the one substance. 
On (a): in addition to positing moral distinctions between different things described above (differences in moral considerability), Schopenhauer states the compassionate person makes "less of a distinction" than others between herself and other sentient beings, not that she makes no distinction (OBM 4:265,249). Shapshay points out that this phrasing reflects one of Schopenhauer's central views about compassion, which is that the compassionate person feels suffering in the other, not in herself: "We suffer with him, thus in him: we feel his pain as his, and do not imagine that it is ours" (OBM 4:211-2, 203).24 This is not merely a phenomenological point. For Schopenhauer, compassion is essentially different from egoism - this is one of the cornerstones of his ethics and moral psychology (see OBM 4:196-9, 190-2). Hence, it seems crucial that the content of compassion involve some sense of the otherness of the object of compassion.

On (b): though the final section of OBM describes a metaphysical view according to which all individuation is mere appearance, Shapshay points out that Schopenhauer himself accepted a doctrine of noumenal Platonic ideas (the main topic of Book 2 of WWRI).

Schopenhauer posits distinct ideas for different species of things, and also distinct ideas for each individual human. Taking up a modified Kantian view of agency, he then equates a human's idea with her 'intelligible character.' 25 Despite not bringing up this point in OBM, Schopenhauer does emphasize it in his discussion of compassion in P\&PII:

the individual character of a person can be regarded as his free act... constituting his original and fundamental willing... Accordingly the entire empirical course of a human life... is as necessarily predetermined as the course of a clock... [T] he result is a moral one, namely that we know what we are by virtue of what we do... From this moreover it follows that individuality does not rest solely on the principium individuationis and is therefore mere appearance through and through; instead, it is rooted in the thing in itself, in the will of the individual, for his character itself is individual (P\&PII 6:242, 206)

Positing distinct ideas and distinct intelligible characters is not compatible with simple monism. Yet Schopenhauer emphasizes that the compassionate person, unlike the egoist or the malicious person, apprehends things correctly. Hence, simple monism cannot be part of the content of compassion for Schopenhauer.

Shapshay's arguments here show that the simple monist interpretation is inadequate. They also, however, give guidance on how the monist interpretation should be developed. Instead of simply saying that the compassionate person perceives that there is no distinction between herself and the object of her compassion, we should say that she perceives them to not be distinct spatiotemporal individuals, that is, she perceives them to be distinct only in the way that Platonic ideas are distinct. The latter distinctness is not sufficient for individuality in the normal sense, for Schopenhauer, since he calls space and time alone the principle of individuation (OBM 4:267, 250). The key difference is that, at the level of ideas, things metaphysically overlap with each other in ways that they do not at the spatiotemporal level.26 Though all humans have their own

24 Shapshay 2019b, 8; Shapshay 2019a, 153-4, 173. Though this passage has rightly attracted commentator's attention, a corresponding but more confusing passage in WWRI is worth keeping in mind, where Schopenhauer calls compassion "cognition of other people's suffering, which is immediately intelligible from one's own suffering and the two are considered the same" (WWRI 2:444, 402; see likewise OBM 4:229, 218 on suffering felt "as mine, yet not in me but in another").

25 See WWRI 2:185, 180; WWRI 2:265, 250; FW 2:48, 68. Schopenhauer holds that a person's inner nature is manifested in their body (see, e.g., WWRI 2:221, 211). Hence, an apprehension of the others' Idea can explain how we feel the pain as in their bodies - something I return to below.

26 Hence, this connection is more than just beings parts of a single entity (cf. Reginster 2015, 272), which can happen at the spatiotemporal level. 
ideas as intelligible characters, they are also all joined through "the Idea of human beings in their unity" (WWRI 2:479, 432; see also WWRI 2:265, 250-51). Not only that, but the idea of the human somehow requires all other ideas as well:

Although it is in the human being, as (Platonic) Idea, that the will finds its clearest and most perfect objectivation, nonetheless, this Idea could not express its essence on its own. In order to appear in its proper significance, the Idea of a human being... must be accompanied by the stepwise descent through all animal forms, through the plant kingdom, and down to the inorganic... they are presupposed in the Idea of a person as the flowers of a tree presuppose leaves, branches, trunks, and roots: they form a pyramid with human beings at the very top. (WWRI 2:182-3, 178)

Referring back to this doctrine later, Schopenhauer claims that, since the idea of humanity somehow contains all other ideas, the genuine annihilation of the former (were that possible) would somehow imply the annihilation of all other ideas. This is all quite unlike the normal individuation of objects in space and time, whose existence appears to be independent of one another:

Nature, always true and naïve, states that the human race would die out if this maxim [of chastity] were universal: and... when the highest appearance of the will has fallen away, then animal existence, its weaker reflection, will fall away as well... If cognition were entirely abolished, the rest of the world would fade into nothing too (WWRI 2:449, 407)

In case one was tempted to think this passage merely concerns appearances, Schopenhauer clarifies shortly thereafter that "[d]eath, in this case, does not just bring an end to appearance.... Rather, the essence itself is abolished" (WWRI 2:452, 409). So his point must be about the interdependence of ideas.

Striking as this last view is, it may only be a corollary of a more radical view. Earlier in WWRI, Schopenhauer indicates that the complete annihilation of any being whatsoever (presumably, down to its idea) would result in the annihilation of everything:

It is not as if there is a smaller part of the will in a stone and a larger part in a person, since the relation between part and whole belongs exclusively to space... It reveals itself just as fully and completely in a single oak tree as in millions... Thus one could say that if, impossibly, a single being, however insignificant, were to be totally annihilated, the whole world would necessarily go down with it. (WWRI 2:152-3, 153-4)27

Hence, in place of the simple monist interpretation, we should say that the compassionate person sees that she and the object of compassion are not distinct individuals, and so are unified at the level of ideas, though some sort of distinction between them remains. Different humans are all unified in the idea of humanity, which itself is united with all other ideas. Those ideas inform the content of compassion, without exhausting it (otherwise, of course the experience would be an aesthetic one). The compassionate person need not think of her insight in such terms, though - as I discuss in $\$ 2.1$ below, her experience might be a phenomenologically simple one that in fact reveals this unity.

27 See also P\&PII 6:236, 201, where Schopenhauer jointly claims (a) that "the world in itself would persist unharmed and undiminished" even if every being in the world except one "perished" and (b) that "when a being, even the slightest, is completely annihilated, in and with it the entire world would have to have perished." 
This less-simple monist picture goes at least part way towards addressing one important objection to Schopenhauer's view, namely, that it dissolves into egoism. As Julian Young puts it: for Schopenhauer, "the altruist does act for the sake of his own interest, the only difference between him and the egoist being that he acts for the sake of the interests of his metaphysical rather than his empirical self." 28 However, given the difference in ideas, some level of distinction remains, so the compassionate agent does not see her 'metaphysical self' as being the same as that of the creature she feels compassion for, even if their metaphysical selves overlap.29

There is another (compatible) interpretive option here worth mentioning. In $\$ 68$ of WWRI, Schopenhauer suggests that the person who most completely sees through appearances feels all suffering as her own, and is thereby moved to leave moral action behind and negate her will through asceticism:

But if this seeing through the principium individuationis, this immediate cognition of the identity of the will in all of its appearances, is present at a high degree of clarity, then it will at once show an even greater influence on the will... [A] human being, who recognizes... his innermost and true self in all beings, must also regard the endless suffering of all living things as his own... this is now all as close to him as his own person is to the egoist... [This] recognition of... the essence of things in themselves such as we described... becomes the tranquilizer of all and every willing. (WWRI 2:447-8, 405-6)

This passage suggests that the compassionate insight involved in moral virtue, while more accurate than what an egoist thinks, is incomplete. Perhaps simple monism really is true at the most fundamental level, but some level of distinction holds at some intermediate level. The compassionate, morally-virtuous person sees below the appearances, but not all the way down, which is why she maintains some sense of distinctness.30 Only the ascetic perceives the ultimate truth of monism, however, though a deeper kind of compassion. Ascetic insight, moreover, produces a "loathing" for the will (WWRI 2:449, 407). Perhaps this happens because only the ascetic perceives that all there is to any being is insatiable willing, whereas moral compassion might leave one room to hope for something else. If this is right, then the simple monist interpretation is correct, provided it describes the ascetic's loathing-inducing insight instead of moral virtue-constituting compassion. For the latter sort of compassion, some non-simple interpretation remains necessary.

\section{Further questions for the Monist Interpretation}

In this section, I turn to several textually-based questions for the monist interpretation that have received only passing mentions in the secondary literature. Addressing these questions

28 Young 2005, 182. The objection was first made to Schopenhauer by Johann August Becker. For discussion, see Cartwright 2010, 509-11. Though many commentators have found the objection compelling, it does not seem obviously forceful to me. What seems morally worthless or vicious is acting for the sake of one's individual self in a way the disregards the interests of other individuals (see Cartwright 2012, 262). Even on the simple monist interpretation, though, that is not what the compassionate person does, since she takes others' interests to be hers as well.

29 For beings without individual characters, however, preservation of their own species might still count as egoistic, then, instead of compassionate. But this seems like the right implication, given Schopenhauer's views on reproduction (e.g., WWRI 2:326-7, 303).

30 Cartwright endorses a similar reading, in a somewhat different context (Cartwright 2012, 250). 
allows us to develop the monist interpretation further while bringing out some surprising aspects of Schopenhauer's view.

\subsection{Is feeling or cognition of unity primary?}

In some places, Schopenhauer seems to suggest that compassion's content involves a mere feeling, whereas in other places he seems to suggest that it involves a recognition of some metaphysical fact. For instance, Schopenhauer claims that, in compassion, we "feel his pain as his, and do not imagine that it is ours" (OBM 4:211-2, 203), but later claims that the compassion involves someone "immediately recognizing himself, his own true essence, in the other" (OBM $4: 270,253$ ). The talk of feeling the others' pain seems important for Schopenhauer's moral psychology, insofar as it helps explain how compassion is able to motivate us to help others in the same way that our own pain motivates us (see OBM 4:229, 218). Moreover, since he takes us to feel others token pains, this phenomenological claim helps motivate his metaphysical explanation of compassion (OBM 2:212, 203). But how exactly does that feeling relate to grasping the fact of one's metaphysical unity with another? After all, it seems one can believe that one is metaphysically unified with others without feeling any motivation regarding them, and it is tempting to think that a mere feeling could not itself be metaphysically informative, especially since Schopenhauer claims that "it is quite wrong to call pain and pleasure representations" (WWRI 2:120, 125).31

I suggest that the most plausible approach here is to take the feeling of another's pain to be the primary content of compassion, and the metaphysical fact of unity to be secondary. There is a fairly straightforward historical precedent for this sort of link between feeling and unity. In the Sixth Meditation, Descartes famously claims that his bodily sensations taught him that he united to this body without being identical to it:

Nature also teaches me, by these sensations of pain, hunger, thirst and so on, that I am not merely present in my body as a sailor is present in a ship, but that I am very closely joined and, as it were, intermingled with it, so that I and the body form a unit.32

Descartes does not seem to hold that pains (and similar feelings) have any complex intrinsic representational structure, so we can understand this as implying that the feeling of pain in my toe when I stub it constitutes an awareness of the fact that I am united with that toe. 33 All that can hold even if, as Descartes thought, the aspect of me most central to my identity (my mind) could exist without the toe. Schopenhauer can be understood as extending this approach beyond the normal boundaries of person. The compassionate person directly feels a token pain in another entity, and that constitutes her awareness of her unity with that other. Because the feeling constitutes that awareness, as opposed to being an inferential basis for it, Schopenhauer can

31 Cartwright recognizes these different options, but, seeing them as incompatible, suggests that most charitable reading avoids attributing metaphysical cognition to the compassionate agent (Cartwright 2008, 301; Cartwright 2012, 263). When Schopenhauer claims that pains and pleasures are not representational, he probably takes them not to have descriptive representational content, which leaves open the possibility of their having, say, imperatival content (see Marshall 2018, 243-7, which draws on Martinez 2011 and Klein 2015). The fact that Schopenhauer gives his core moral principle in imperatival form gives indirect evidence for this possibility (see $\$ 2.4$ below).

32 Descartes 1999, 56 (AT 7:81).

33 In his correspondence with Princess Elisabeth, Descartes explains that such feelings somehow involve a "primitive notion" of the mind-body unity (Descartes 2007, 65; AT 3:665). Arguably, even that would be too much representational content for Schopenhauer. 
coherently hold that compassion involves an immediate recognition of the unity (see, e.g., OBM 4:270, 253), which points to the next question I'll consider.

Before moving on, however, two more points are worth making. First, saying that the compassionate person directly or immediately feels another's token pain does not imply that she has a complete compassionate grasp of it. Just as I can perceive the shape of an object (say, that it is cubical) without having every aspect of its shape revealed to me, so too can Schopenhauer hold that compassion involves feeling others' pains without fully grasping their internal affective state. Hence, he writes that, for the compassionate person, "the suffering he sees in others affects him almost as much as his own" (WWRI 2: 440, 399, my emphasis, see also OBM 4:209, 200). Second, though Schopenhauer's examples of compassion focus on suffering, and says that compassion "is restricted to [another's] suffering and is not also aroused, at least not directly, by his well-being" (OBM 4:210, 202), compassion is not limited to simple states of pain. Remember that Schopenhauer defines "suffering" in very general terms, as all "unfulfilled and thwarted willing" (WWRI 2:429, 390). Similarly, in OBM, he says that once the distinction between I and not-I drops away, "only then does the other's business, his need, his distress, his suffering [Angelegenheit des Andern, sein Bedürfniss, seine Noth, sein Leiden] immediately become mine" (OBM 4:229, 218). Not only does this show the breadth of compassion for Schopenhauer, but it helps show how compassion can move us to refrain from harming or otherwise interfering with others who are not yet experiencing pain or disappointment: we can feel their current 'business' as they strive towards goals they have not reached. 34

\subsection{How do cognitions mediate compassion?} instance:

Schopenhauer emphasizes that the insight involved in compassion is 'immediate'. For

for awakening compassion, which has been proved as the sole source of disinterested actions and consequently as the true basis of morality, no abstract cognition was required, but only intuitive cognition, the simple grasp of the concrete instance, to which compassion responds at once [Sogleich] without further mediation of thought [Gedankenvermittlung]. (OBM 4:246, 232)

a truly good disposition, disinterested virtue, and nobility of mind do not start with abstract cognition, but do nonetheless begin with cognition - namely, an immediate [unmittelbaren] and intuitive cognition that cannot be reasoned for or reasoned away, a cognition that cannot be communicated precisely because it is not abstract. (WWRI 2:437, 396-97) 35

However, Schopenhauer also claims, that compassion requires cognition of the other:

since I am not lodged in the skin of another, it is solely by means of [vermittelst] the cognition that I have of him, i.e., the representation of him in my mind, that I can identify

34 Along similar lines, Bernard Reginster glosses Schopenhauer's compassion in terms of felt desires (Reginster 2015, 261). This provides part of an answer to David Cartwright's objection that Schopenhauer cannot explain how compassion grounds the virtue of justice, that is, the virtue of not harming (Cartwright 2012, 260-61). I give the rest of an answer below.

35 Schopenhauer sometimes suggests that our cognition of others' suffering just is our own suffering in some sense: "the only thing that can ever move [people] to perform good deeds and works of charity is the cognition of other people's suffering, which is immediately intelligible from one's own suffering and the two are considered the same" (WWRI 2:444, 402). 
with him to such an extent that my deed proclaims that distinction [on which egoism and malice rests] to be removed (OBM 4:208, 200)

This latter claim seems plausible: we feel compassion for other beings only if we have some antecedent awareness of their existence and the fact (or potential fact) of their suffering. Yet that would seem to mean that cognition mediates compassion, which would contradict Schopenhauer's claims about compassion's immediacy.36

I suggest that we can resolve this tension by considering an analogous aspect of Schopenhauer's aesthetics. Fine art, for Schopenhauer, provides us an occasion for an immediate apprehension of the Platonic ideas. For example, he claims that "the great task of historical painting and of sculpture is the immediate and intuitive presentation of the Idea in which the will reaches the highest degree of its objectification [i.e., the Idea of the human]" (WWRI 2:260, 2456). Here we have another apparent tension, since it would seem that a (spatiotemporal) historical painting or sculpture helps, and so mediates, our awareness of the (non-spatiotemporal) idea. Yet the resolution of the tension in this case seems relatively straightforward: the painting positions or prompts us to have the immediate awareness of the idea. In the case of compassion, therefore, we can say that the cognition positions or prompts awareness of the others' pain, but that awareness, once it happens, is nonetheless immediate.

This proposal can be reinforced by considering whether compassion, for Schopenhauer, extends to entities for which we have no present perception.

\subsection{Is compassion confined to the present?}

If compassion involves accurately and immediately feeling another's suffering, then it is tempting to think that the other's suffering must be actual and present, and therefore that Schopenhauer can only allow for compassion with entities that presently exist. 37 This would be a significant restriction, especially since many of Schopenhauer's own examples of compassion seem to involve anticipatory compassion - e.g., his case of Titus, who refrains from killing a rival when he realized "what would really happen to him" (OBM 4:232 - OUP 234). In cases like this, the suffering the compassionate person feels averse to is not merely non-present, but also nonactual, since it never comes to be. In some cases, it might be enough to have compassion for a person's current striving or 'business' (as noted in $\$ 2.1$ above), but an adequate theory of compassion as the basis for ethics should also apply to entities, such as future generations, with no present conscious states at all.

Fortunately, Schopenhauer's monism does not require a restriction to the present and the actual. He takes space, time, and modality to be metaphysically ideal. While the discussion in OBM only mentions the ideality of space and time (e.g., OBM 4:267), in WWRI he states explicitly that compassion goes beyond the actual:

From the perspective of the true nature of things, everyone must regard all the sufferings of the world as his own; in fact, he must regard all merely possible suffering as actual, so long as he is the steadfast will to life, i.e. so long as he affirms life with all his strength. (WWRI 2:417, 380, my emphasis)

36 Reginster seems to think that Schopenhauer only takes awareness of others' suffering to be mediated for the egoist (Reginster 2015, 266), but passages like the above show that an interpretive paradox of immediacy arises for the compassionate agent as well.

37 David Cartwright makes this argument, taking it as grounds for saying that Schopenhauer cannot derive the virtue of justice from his own account of compassion, and that he should have instead have based it merely in imaginative representation instead of in metaphysical perception (Cartwright 2012, 260-61). 
All the miseries of others that he sees and is so rarely in a position to alleviate, all the miser he learns about indirectly or in fact only knows to be possible, all these affect his spirit as if they were his own... as he sees through the principium individuationis, everything is equally close to him. (WWRI 2:447, 405, my emphasis)

The latter passage here is drawn from $§ 68$, where Schopenhauer discusses how compassion ultimately leads beyond moral virtue to the denial of the will. So Schopenhauer seems to think that full compassion with the actual and the non-actual leads to the quieting of the will. While that full compassion might always take subjects beyond moral virtue, Schopenhauer can coherently hold that moral virtue involves compassion for some merely possible suffering.

Extending compassion beyond the actual also makes Schopenhauer's ethical views more plausible. One common criticism of compassion and related phenomena like empathy is that they are biased towards present entities - illustrated perhaps most tragically by otherwise decent people's indifference towards the suffering of distant migrants and future generations. 38 For Schopenhauer, however, restricting compassion to the present would be akin to the error of egoism, which also privileges the here and now. By tying compassion to the realization of any being's suffering anywhere, he has an epistemic basis for criticizing many actual instances of compassion as being short-sighted.

\subsection{How does the content of compassion relate to Schopenhauer's imperatival principle?}

In the previous three subsections, I suggested several refinements to the monist interpretation. One might object, though, that these refinements go beyond what Schopenhauer himself thought, given the simplicity of his central moral principle: "Harm no one, rather help everyone to the extent that you can" (OBM 4:137, 140). This principle, which he takes to be based on compassion, says nothing about the priority of feeling, metaphysical unity, immediacy, time, or modality. Yet it is, he holds, the "reservoir" or "container" of compassion (OBM 4:214, 205), which provides the basis for much compassionate action. 39 Hence, we have some grounds for denying that Schopenhauer took compassion to have the sort of content I have been describing.

However, Schopenhauer did not hold that articulable moral principles could fully capture the content of compassion. Recall his claim that virtue "does indeed come from cognition, but not from abstract cognition that can be communicated through words" (WWRI 2:434, 395) and that the compassionate insight "is not truly and adequately expressed in words" (WWRI 2:437, 397). More generally, he holds that abstract knowledge is to intuition "as a mosaic is to a van der Werft or a Denner", that is, to use a contemporary metaphor, that abstract knowledge is necessarily more course-grained (WWRI 2:67, 81). We should expect, then, that the abstract principle would be merely a partial reflection of the content of compassion. As Shapshay notes, we might regard it as a "rule of thumb" (Shapshay 2019a, 185). While the principle stores up compassionate motivation, that process of storage might lose some of the structure and detail of the original

${ }_{38}$ See Prinz 2011, Bloom 2016. In a similar vein, Shapshay worries that compassion is not sufficient for right action, and needs to be combined with reason to appropriately engage with non-present suffering (Shapshay 2019a, 163-4). In earlier work, I suggested distinguishing between short-range and long-range compassion, where the latter has a more plausible connection the morality (Marshall 2018, 13; see Reginster 2015, 257 on a similar idea in Nietzsche).

39 Shapshay holds that acting from the principle is not acting from compassion (Shapshay 2019a, 203). Though there is a sense in which this is right, Schopenhauer's metaphor suggests that the principle 'stores' compassionate motivation for later action. By analogy: one can store spring water to drink later, and when one drinks it later, one is still drinking spring water. 
compassion, just as bread loses its original texture when reg. Hence, we should not think that we can read the content of compassion or virtue directly off of Schopenhauer's moral principle.

That answer might seem to raise its own difficulty, though. In this paper, I have been using words to describe the content of compassion. I take it that these words, like the ones from Schopenhauer I have been citing, should be seen as the best we can do in reflecting on the content of compassion, but no substitute for the real thing. This gives us an additional reason to take the feeling of another's pain as the primary element of compassion, since it is a familiar thought that one cannot really know pain without experiencing it.

Here, then, is the refined monist interpretation of Schopenhauer's views of the content of compassion. Prompted by some sort of cognition of Y, X immediately (but incompletely) feels Y's (actual or non-actual, present or non-present) pain, which thereby constitutes her awareness that she is united to Y.40

\section{Conclusion: Monism and Inherent Value?}

In the introduction, I bracketed the question of whether a monist interpretation could be combined with an axiological interpretation like Shapshay's. One way to bridge the monist and inherent value interpretations would be to find some definitional or conceptual truth about value that implied that the monistic insight concerned value. By analogy: it is arguably conceptually true that anything scarlet is red. If I see that some flowers are scarlet, then, we can also say that, I also see that some flowers are red (at least insofar as I have the relevant concepts). To conclude, I want to point to some textual grounds for thinking Schopenhauer accepted some such bridge between monistic content and evaluative content.

Bernard Reginster has claimed that Schopenhauer rejects the very possibility of intrinsic value, given his broadly instrumentalist definition of "good" as "the suitability of an object to any particular effort of the will" (WWRI 2:425, 387; see also OBM 4:161, 161 on "worth"). Reginster takes this to mean that recognizing another as good, for Schopenhauer, therefore is merely a matter of recognizing them as egoistically useful.41 Against Reginster, Shapshay proposes that Schopenhauer also implicitly recognizes a non-instrumental and non-relative sense of goodness that applies to the inherent value of sentient beings.42 However, it is not obvious that moral goodness must be inherent goodness, and it is possible to hold that some forms of goodness are necessary and universal without being inherent (the latter is sufficient, e.g., to avoid distasteful moral relativism). Some constuctivist Kantian views appeal to something along these lines, 43 and Schopenhauer himself suggests as much just after introducing the definition of 'goodness' that Register mentions:

As with all other beings that can entertain relations with the will, people also called human beings good if they were advantageous... to the goals that were being willed at the moment... Now it was in some people's character not to get in the way of the

40 As Cartwright suggests, the difference between morally just and fully compassionate agents may be a matter of how profoundly they feel this compassion (Cartwright 1988, 33), though this topic deserves more discussion. One might also ask: how does fuller compassion lead to resignation? Here is the start of an answer: if (as I suggested in \$1.3), ascetic compassion involves a simple apprehension of the will, then the subject of such compassion feels the unsatisfiablility of all existence. Such an apprehension leaves no room for thoughts of alternatives, and so no hope. This might understandably then lead to a loathing for the will (WWRI 2:449, 407; see also Cartwright 1988, 35).

41 Reginster 2012, 162.

42 Shapshay 2019a, 180.

43 See Langton 2007 for a helpful discussion. 
endeavours of the will of others, but rather to promote them, and they were thus thoroughly helpful, benevolent, friendly and charitable; they were called good human beings, because of the way their actions related to the wills of others in general. (WWRI $2: 426,387$, my emphasis)

In short, compassionate people are necessarily and universally good, since compassion makes one suitable to other efforts of will through non-interference (in the virtue of justice) and helping (in loving-kindness). Contrary to what Reginster suggests, then, a subject can recognize that certain others are good not merely in the sense of being useful to her, but also, if they are compassionate, as being generally useful. It is not odd to see a link between general usefulness and moral value after all, David Hume defined moral virtue partly in terms of general usefulness.44

The line of thought just described implies only that compassionate people are good, not that every sentient being (sentient of otherwise) has value. On the other hand, Schopenhauer claims that "[t]he three fundamental ethical incentives of human beings, egoism, malice, compassion, are present in each one in different and incredible diverse proportions" (OBM 4:252, 23845), and that some small degree of compassion generates the anguish of conscience in evildoers (see WWRI 2:432, 393). Hence, at least all humans, on Schopenhauer's view, will have some degree of goodness that potentially could be revealed in a compassionate apprehension of their wills.46 Insofar as this concerns only humans, and suggests there are wildly different degrees of goodness corresponding to different levels of compassion, it falls short of Shapshay's inherent value interpretation, on which all sentient beings have roughly the same value (Shapshay 2019a, 183). Shapshay's interpretation is not only philosophically attractive, it also has some textual basis, for Schopenhauer objects to the "denial and defamation" of non-human animals in other moral systems (OBM 4:239, 227, cited at Shapshay 2019a, 182), and seems to attribute "unfathomable significance" ("unergründerlicher Bedeutsamkeit") to "everything that has life" (OBM 4:162, 162, cited at Shapshay 2019a, 18).47

However, there is another route to grounding inherent value in the monist interpretation, though it requires going one step beyond the text. Schopenhauer aside, the following seems like a plausible conceptual truth: if it is intrinsically pro tanto wrong to interfere with X's activity, then $\mathrm{X}$ has some moral value (or worth, significance, dignity, etc.). For example, interfering with the activity of a computer is not intrinsically wrong, since computers have no moral value. However, it does seem intrinsically pro tanto wrong to interfere with a person's activities on a computer (say, by pulling the plug), since people do have some moral value. Other factors might override the pro tanto wrongness, of course, but part of what we have in mind in taking an entity to be

44 Hume took our core moral sentiments to be responses to qualities of others that are generally useful and agreeable (Hume 1983). Schopenhauer does not engage with Hume's ethical views, which is odd, given his admiration of Hume and his detailed knowledge of his work (see Cartwright 2010, 177, 418-19).

45 In WWRII 3:697, 607, he acknowledges a fourth ultimate motive, connected to asceticism, which is the pursuit of one's own woe. It is not obvious how to categorize this motive morally.

46 At WWRI 2:417, 379, Schopenhauer mentions the possibility that, in addition to humans, "even the more intelligent animals" might have some share of compassion.

${ }_{47}$ Cf. WWRI 2:113, 119 for a related use of "Bedeutung." In the same OBM passage, Schopenhauer seems to imply that humans rightly see themselves as valuable ('werthe'), though he elsewhere states that humans are "on the whole worthless" (WWRI 2:415, 378). But Shapshay takes Schopenhauer to be internally conflicted about the value of existence, so passages like the latter do not threaten her reading (see also Murdoch 1993, 65). Moreover, we can understand the claim about human worthlessness in terms of how much compassion and so genuine usefulness (Humean virtue) they have (for Schopenhauer's dimmest statement on the extent of human compassion, see OBM 4:198, 192), which is independent of other types of value. 
morally valuable is that interfering with her activity is morally problematic. Schopenhauer might not explicitly endorse this notion of moral value (he says that "non-comparative, unconditioned, absolute worth... simply cannot be thought (OBM 4:167, 166)), but that may not matter much: we might simply have a different concept of value or worth than he does. Yet, using this wronging-based notion of moral value, it will follow from Schopenhauer's views that every being has moral value. For he defines wrongness just as the interference with or "violation of the boundaries" of another's will (WWRI 2:394, 360), and holds that every being's activities stem from its will (see WWRI 2:136-7, 140). Since his definition of wrongness invokes no extrinsic factors, it implies that all interference with other beings' wills is intrinsically wrong. It becomes clear that this wrongness is pro tanto, which is why Schopenhauer thinks it is permissible to eat animals (OBM 4:245, 231). Therefore, provided we acknowledge that we are using a notion of moral value or worth that Schopenhauer himself does not explicitly endorse, we can say that compassion does reveal what amounts to moral worth, insofar as it reveals facts about suffering, which itself arises from interference with others' willing. Hence, a monist reading can come very close to Shapshay's inherent value interpretation. The two interpretations agree that we would not be motivated to help others if we saw them as worthless (cf. Shapshapy 2019, 180), though the monist reading does not say that perceiving others as valuable explains the motivation to help them, but rather that our motivation constitutes or provides the basis for the more intellectual state of perceiving others as valuable (arguably thereby making normal compassion simpler).

I have not attempted to argue for the philosophical plausibility of metaphysical monism here, and I expect that most readers who find Schopenhauer's views on compassion otherwise attractive will want to find ways to set it aside. Nonetheless, having a fuller understanding of the metaphysical content Schopenhauer attributes to compassion promises to improve our understanding of how compassion fits into his larger system. It also should encourage us to think about what metaphysical content compassion might have, a topic that has received relatively little attention in the European philosophical tradition. 48

${ }_{48}$ For helpful feedback and conversations, I am grateful to Mike Raven, Sean Murphy, the students in my Fall 2019 class on Schopenhauer's ethics, and especially Sandy Shapshay. 


\section{Works Cited}

Bloom, Paul. 2016. Against Empathy. New York: Ecco.

Cartwright, David. 2008. 'Compassion and Solidarity with Sufferers: The Metaphysics of Mitleid.' European Journal of Philosophy 16:2, 292-310

-- 2012. 'Schopenhauer and the Value of Compassion' in Bart Vandenabeele (ed) A Companion to Schopenhauer (Blackwell 2012),249-265

-- 2010. Schopenhauer: A Biography. Cambridge: Cambridge University Press.

-- 1988. "Schopenhauer's Axiological Analysis of Character." Revue Internationale de Philosophie 42:164, 18-36.

Descartes, René. 2007. The Correspondence between Princess Elisabeth of Bohemia and René Descartes. Chicago: University of Chicago Press.

-- 1999. The Philosophical Writings of Descartes, Vol. II.

Hume, David. 1983. An Enquiry Concerning the Principles of Morals, J.B. Schneewind (ed.). Indianapolis: Hackett Press.

Janaway, Christopher. 2007. Beyond Selflessness: Reading Nietzsche's Genealogy. Oxford: Oxford University Press.

Klein, Colin. 2015. What the Body Commands. Cambridge, MA: MIT Press.

Kripke, Saul. 1979. “A puzzle about belief.” In A. Margalit (ed.), Meaning and Use. Dordrecht: Reidel. 239-83.

Langton, Rae. 2007. "Objective and Unconditioned Value”. Philosophical Review 116:2, 157-85.

Marshall, Colin. 2018. Compassionate Moral Realism. Oxford: Oxford University Press.

-- 2017a. "Schopenhauer and non-cognitivist moral realism." Journal of the History of Philosophy 55: 2 (2017), 293-316.

-- 2017b. "Schopenhauer and Contemporary Metaethics", in The Palgrave Schopenhauer Handbook, Sandra Shapshay (ed).

Martinez, Manolo. 2011. "Imperative Content and the Painfulness of Pain." Phenomenology and the Cognitive Sciences 10, 67-90.

Murdoch, Iris. 1993. Metaphysics as a Guide to Morals. New York: Penguin.

Prinz, Jesse. 2011. "Is Empathy Necessary for Morality?” In Amy Coplan and Peter Goldie (eds.), Empathy: Philosophical and Psychological Perspectives. Oxford: Oxford University Press, 211-29. 
Reginster, Bernard. 2012. "Compassion and Selflessness" in Christopher Janaway and Simon Robertson (eds), Nietzsche, Naturalism and Normativity. Oxford: Oxford University Press, 160182.

-- 2015. "Sympathy in Schopenhauer and Nietzsche" in Eric Schliesser (ed.) Sympathy: A History (Oxford: Oxford University Press 2015), pp. 254-86

Shapshay, Sandra. 2019b. "Was Schopenhauer a Kantian Ethicist?” International Journal of Philosophical Studies. Online version: https://doi.org/10.1080/09672559.2019.1692056

-- 2019a. Reconstructing Schopenhauer's Ethics. Oxford: Oxford University Press.

-- 2008. "Poetic Intuition and the Bounds of Sense: Metaphor and Metonymy in Schopenhauer's Philosophy.” European Journal of Philosophy 16:2, 211-229.

Schopenhauer, Arthur. 2010. The World as Will and Representation. Vol 1. Trans. and ed. Judith Norman, Alistair Welchman and Christopher Janaway. Cambridge: Cambridge University Press.

Schopenhauer, Arthur. 1969. The World as Will and Representation. Vol 2. Trans. EJF Payne New York: Dover.

Schopenhauer, Arthur. 2009. The Two Fundamental Problems of Ethics. Ed. and trans. Christopher Janaway. Cambridge: Cambridge University Press.

Welchman, Alistair. Unpublished. "Schopenhauer and Compassion." 